\title{
Analysis of Ghrelin and Asymmetric Dimethylarginine (ADMA) as Endothelial Dysfunction Marker Among Obese Men
}

\author{
Lia Meliani ${ }^{1,2},{ }^{*}$ Mansyur Arief ${ }^{3}$, Indriyanti Rafi Sukmawati, ${ }^{1,2}$ \\ ${ }^{1}$ Prodia Clinical Laboratory, Jl. Cisangkuy No.2, Bandung, Indonesia \\ ${ }^{2}$ Post Graduate Program in Clinical Biochemistry, Jl. Perintis Kemerdekaan Km.10. Makassar, Indonesia \\ ${ }^{3}$ Faculty of Medicine, Hasanuddin University, Jl. Perintis Kemerdekaan Km.10. Makassar, Indonesia \\ *Correspondence: lia.meliani@prodia.co.id
}

\section{Abstract}

$\mathrm{B}$ ACKGROUND: Ghrelin has many biological activities such as regulating energy homeostasis and recent studies have shown its effects in the cardiovascular system. Ghrelin concentration decreases in obese man that indicates relationship between ghrelin and energy homeostasis. Ghrelin also improves endothelial function by increasing the bioavaibility of nitric oxide (NO). The bioavaibility of NO is also influenced by ADMA. ADMA is an endogenous competitive inhibitor of endothelial nitric oxide synthase (eNOS), which is significantly elevated during endothelial dysfunction. This study aimed to evaluate the relationship of ADMA and ghrelin with central obesity based on waist circumference and to evaluate the relationship of total ghrelin and ADMA in centrally obese men.

METHODS: Total ghrelin and ADMA were measured in 20 non-obese men (waist circumference (WC) 78.85 $\pm 4.40 \mathrm{~cm}$ ) and 60 centrally obese men (WC $97.54 \pm$ $5.94 \mathrm{~cm}$ ). Anthropometric measurements (height, weight, BMI, waist circumferences and blood pressure) were also recorded. Statistics were carried out by the Spearman and Pearson bivariate correlation analysis and independent sample $\mathrm{T}$ test.

\section{Abstrak}

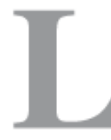

ATAR BELAKANG: Ghrelin memiliki banyak aktivitas biologis seperti regulasi homeostasis energi dan studi terbaru menunjukkan kerjanya dalam sistem kardiovaskular. Konsentrasi ghrelin menurun pada pria obes yang mencerminkan adanya hubungan antara ghrelin dan homeostasis energi. Ghrelin juga diketahui dapat memperbaiki disfungsi endotel dengan meningkatkan bioavaibilitas nitric oxide (NO). Bioavaibilitas NO juga dipengaruhi oleh ADMA. ADMA merupakan inhibitor kompetitif endothelial nitric oxide synthase (eNOS) endogen, yang secara signifikan meningkat pada kondisi disfungsi endotel. Studi ini bertujuan untuk mengevaluasi hubungan antara ADMA dan ghrelin pada obesitas sentral dan mengevaluasi hubungan antara ghrelin total dan ADMA pada pria dengan obesitas sentral.

METODA: Konsentrasi ghrelin total dan ADMA ditentukan pada 20 pria non-obes (lingkar perut/waist circumference (WC) 78,85 $\pm 4,40 \mathrm{~cm}$ ) dan 60 pria obes (WC 97,54 $\pm 5,94 \mathrm{~cm}$ ). Pengukuran antropometrik (tinggi badan, berat badan, BMI, WC, dan tekanan darah) juga dilakukan. Statistik dilakukan dengan menggunakan analisa korelasi Spearman and Pearson serta independent sample T test. 
RESULTS: ADMA concentrations were significantly higher in centrally obese men than in normal weight controls (p-value $<0.05$ ), whereas total ghrelin concentrations were not significantly lower in centrally obese men than in normal weight controls ( $\mathrm{p}$-value $>0.05$ ). Ghrelin total concentrations were significantly lower in centrally obese men with metabolic syndrome than in normal weight controls (p-value $<0.05$ ). No significant correlation existed between total ghrelin and ADMA.

CONCLUSIONS: No correlation existed between ADMA and total ghrelin. The pathway of ghrelin in altering vascular function may not involve ADMA.

KEYWORDS: ghrelin, ADMA, endothelial dysfunction, obese

Indones Biomed J 2012; 4 (2): 93-100
HASIL: Konsentrasi ADMA lebih tinggi secara signifikan pada pria dengan obesitas sentral apabila dibandingkan dengan kelompok kontrol ( $p$-value $<0.05$ ), sementara konsentrasi ghrelin total tidak lebih rendah secara signifikan pada kelompok obes bila dibandingkan kelompok kontrol ( $p$-value $>0.05$ ). Konsentrasi ghrelin total secara signifikan lebih rendah pada kelompok obes dengan sindrom metabolik bila dibandingkan kelompok kontrol ( $p$-value $<0.05)$. Tidak terdapat korelasi signifikan antara ghrelin total dan ADMA.

KESIMPULAN: Tidak ada korelasi antara ADMA dan ghrelin total. Jalur ghrelin dalam mempengaruhi fungsi vaskular kemungkinan tidak melalui ADMA.

KATA KUNCI: ghrelin, ADMA, disfungsi endotel, obesitas

Indones Biomed J 2012; 4 (2): 93-100

\section{Introduction}

Ghrelin is a 28 -amino acid peptide that is excreted particularly by P/D1 cells in gastric oxyntic mucosa of human. Ghrelin has many biological activities prominently in the regulation of food intake, gastrointestinal motility, energy homeostasis, modulation of reproductive, cardiovascular, and immune functions (1). Ghrelin was originally reported as an agonist for the orphan growth hormone secretagogue reseptor (GHSR), which induces release of growth hormone. Other studies have indicated many other physiological activities of ghrelin including regulation of food intake and energy balance as well as in lipid and glucose metabolism. Furthermore, ghrelin has a variety of cardiovascular actions for example increasing vasodilation and regulating blood pressure (2).

Not only is it found in the stomach, ghrelin also found in the hypothalamus, pituitary gland, hippocampus, brain cortex, adrenal gland, intestine, pancreas, and many other human tissues (3) such as liver, kidney, adipose tissue (4), placenta, testes, ovary, and lymphocytes (2).

Ghrelin is an endogenous ligand for the GHSR. GHSR is a typical G-protein coupled, with seven transmembrane domain receptors and consists two types of GHSR i.e. GHSR 1a and GHSR 1b. GHSR 1a binds to ghrelin and leads to intracellular calcium mobilization but GHSR $1 \mathrm{~b}$ is not able to bind to ghrelin. GHSR 1a is prominently found in the hypothalamus and the pituitary but is also found in other tissues such as central nervous system, pancreas, lung, liver, kidney, intestines, myocardium, lymph, ovary, testes, adrenal, adipose tissue, and stomach. Other authors have shown that human endothelial cells (ECs) express ghrelin and the presence of ghrelin receptor has been reported in human ECs, vascular smooth muscle cells, and the left ventricle (2).

However, the molecular mechanisms of ghrelin vascular activity still need to be investigated. Other studies have found that ghrelin activates eNOS in cultured ECs and in intact vessels. Ghrelin induces phosphorylation of eNOS on an activation site and production of $\mathrm{NO}$ in human umbilical vein ECs and bovine aortic ECs. The molecular mechanism that underlines the activity of ghrelin in induced phosphorylation of eNOS is based on its activity in stimulated AMP-activated protein kinase (AMPK) and Akt (also called protein kinase B) activation in cultured ECs and intact vessels. Akt has been an important kinase phosphorylating human eNOS at Ser-1177 which increases activity of eNOS in response to various stimuli such as fluid shear stress and insulin. Recently, AMPK (trimeric enzyme comprising a catalytic $\alpha$-subunit and regulatory $\beta, \gamma$-subunits) has also been suggested to phosphorylate eNOS at Ser-1177, which causes eNOS activation (5). 
ADMA, an analogue of L-arginine, is a product of metabolism found in human circulation naturally. The increase of ADMA concentration can inhibit NO synthesis and therefore impair endothelial function (6). This existing knowledge is the foundation for this research to observe the association between ADMA and total ghrelin in centrally obese man.

\section{Methods}

\section{SUBJECTS RECRUITMENT}

In this cross-sectional, observational study, 80 participants were divided into two groups. Group A consisted of 20 men with waist circumference $<90 \mathrm{~cm}$, and group B comprised 60 men with waist circumference $\geq 90 \mathrm{~cm}$. All the study subjects were recruited by simple random sampling method. Inclusion criteria were as follows: age 30-55 years, willing to follow the research protocols and sign the informed consent which had been approved by the Ethics Review Committee of the Faculty of Medicine, Hassanudin University, No. 0202/H4.8.4.5.31/PP36KOMETIK/2012 with register no. UH12010012. All subjects who consumed medication such as lipid-lowering drugs, aspirin, ACE inhibitor and ARB, drink alcohol, had kidney disease (eGFR $<60 \mathrm{~mL} / \mathrm{min} / 1.73 \mathrm{~m}^{2}-$ MDRD), liver enzyme abnormality (AST and/or ALT 2xULN), fasting blood glucose $\geq 126 \mathrm{mg} / \mathrm{dL}$ and high-sensitivity C-reactive protein (hsCRP) concentration $>10 \mathrm{mg} / \mathrm{L}$, were excluded from the study.

\section{STATISTICAL ANALYSIS}

All statistical tests were performed using SPSS ver. 16 . Data were analyzed by Spearman and Pearson bivariate correlation and independent sample $\mathrm{T}$ test for comparisons between groups. Data expressed as means \pm SD. p-value $<0.05$ were considered as statistically significant. The sign of $(* *)$ indicates that correlation is significant at the 0.01 level (2-tailed) and (*) indicates that correlation is significant at the 0.05 level (2-tailed).

\section{MEASUREMENT OF ADMA}

ADMA concentration was examined with ADMA-ELISA kit (DLD Diagnostika GmbH, Hamburg, Germany). The competitive ADMA $®$-ELISA uses the microtiter plate format. ADMA is bound to the solid phase of the microtiter plate. ADMA in the samples is acylated and competed with solid phase bound ADMA for a fixed number of rabbit anti-ADMA antiserum binding sites. When the system was in equilibrium, free antigen and free antigen-antiserum complexes were removed by washing. The antibody bound to the solid phase ADMA was detected by anti-rabbit/peroxidase. The substrate $\mathrm{TMB} /$ peroxidase reaction was monitored at $450 \mathrm{~nm}$. The amount of antibody bound to the solid phase ADMA was inversely proportional to the ADMA concentration of the sample. Optical density values were measured at $450 \mathrm{~nm}$ (reference wavelength between 570 and $650 \mathrm{~nm}$ ) in a microplate photometer.

\section{MEASUREMENT OF TOTAL GHRELIN}

Total ghrelin was examined with Total Ghrelin- ELISA kit (DRG International, Inc., USA). The active ghrelin molecule is extremely unstable in serum/plasma and should be rigorously protected during blood sample collection. For maximum protection, we added Pefabloc or AEBSF and did acidification of all samples. Acidification would result in noticeable protein precipitation but it did not affect the assay. This assay was a Sandwich ELISA method. The enzyme activity was measured spectrophotometrically in microplate photometer by the increased absorbency at $450 \mathrm{~nm}$, corrected from the absorbency at $590 \mathrm{~nm}$, after acidification of formed products.

\section{Results}

\section{Subject characteristics}

As shown in Table 1, the mean \pm SD of total ghrelin concentration was $509.48 \pm 235.24 \mathrm{pg} / \mathrm{mL}$ and the mean \pm SD of ADMA concentration was $0.64 \pm 0.12 \mu \mathrm{mol} / \mathrm{L}$. Total ghrelin concentrations in non-obese subjects was $602.60 \pm 349.18$ and $478.43 \pm 175.82$ in centrally obese subjects (Table 2). The mean \pm SD of ADMA in non obese and centrally obese subjects is also shown in Table 2 .

There was no significant difference between total ghrelin concentration in centrally obese men and in nonobese men (p-value $>0.05$ ) but significant difference was found between ADMA in centrally obese men and non-obese men (Table 2). Ghrelin concentration was significantly different between the group with centrally obese men and metabolic syndrome and the group of nonobese men (p-value <0.05). The total ghrelin concentration in obese subjects with metabolic syndrome was $536.80 \pm$ $195.43 \mathrm{pg} / \mathrm{mL}$. 


\section{Correlation between waist circumference and total ghrelin}

The circulating total ghrelin concentrations tended to correlate negatively with waist circumference $(r=-0.244$ *, $\mathrm{p}$-value $=0.029)$ and BMI $\left(\mathrm{r}=-0.261^{*}\right.$, $\mathrm{p}$-value $\left.=0.019\right)$, and the correlation was significant.

\section{Correlation between waist circumference and ADMA}

The circulating ADMA concentrations tended to correlate negatively with waist circumferences $(r=0.206$, $p$-value $=0.067)$ and BMI $(\mathrm{r}=0.114$, p-value $=0.313)$, but the correlation was not significant.

\section{Correlation between total ghrelin and other parameters}

The fasting total ghrelin concentrations were negatively significantly correlated with fasting blood glucose (FBG)
( $\mathrm{r}=-0.315$, p-value $<0.05)$, but were not significantly correlated with blood pressure, log hsCRP and ADMA concentrations $(r=-0.045$, p-value $>0.05)$. The correlation between total ghrelin and ADMA was also evaluated in several groups such as non obese, central obesity, obese non metabolic syndrome and obese with metabolic syndrome group (Table 3 ).

\section{Correlation between ADMA and other parameters}

The circulating ADMA concentrations tended to significantly correlate with age $\left(\mathrm{r}=0.309^{* *}\right.$, $\mathrm{p}$-value $=$ 0.002), HDL chol $\left(r=-0.335^{* *}\right.$, p-value $\left.=0.002\right), \log$ triglyceride $\left(\mathrm{r}=0.297^{*} *\right.$, p-value $\left.=0.008\right)$, and SBP $(\mathrm{r}$ $=0.319$, p-value $=0.004)$ but not significantly correlated with $\log$ hsCRP and total ghrelin.

Table 1. Characteristic of research subjects

\begin{tabular}{|c|c|c|c|c|c|}
\hline & Mean \pm SD & Median & Mode & Min & Max \\
\hline Age (year) & $40.96 \pm 6.16$ & 40 & $39 a$ & 30 & 55 \\
\hline $\operatorname{BMI}\left(\mathrm{kg} / \mathrm{m}^{2}\right)$ & $26.79 \pm 4.16$ & 27.06 & $26.99^{a}$ & 18.70 & 36.46 \\
\hline$W C(\mathrm{~cm})$ & $92.87 \pm 9.87$ & 93 & 92 & 71 & 113 \\
\hline $\mathrm{SBP}(\mathrm{mmHg})$ & $120.12 \pm 11.75$ & 120 & 120 & 90 & 147 \\
\hline $\mathrm{DBP}(\mathrm{mmHg})$ & $79.74 \pm 8.52$ & 80 & 80 & 60 & 106 \\
\hline Ghrelin Total (pg/mL) & $509.48 \pm 235.24$ & 466 & $315^{\mathrm{a}}$ & 17 & 1378 \\
\hline ADMA $(\mu \mathrm{mol} / \mathrm{L})$ & $0.64 \pm 0.12$ & 0,62 & 0.62 & 0,44 & 1.03 \\
\hline $\mathrm{FBG}(\mathrm{mg} / \mathrm{dL})$ & $94.09 \pm 9.52$ & 93 & 92 & 76 & 120 \\
\hline AST (U/L) & $24.96 \pm 8.69$ & 23.50 & 24 & 12 & 59 \\
\hline ALP (U/L) & $32.91 \pm 18.36$ & 27 & 24 & 10 & 80 \\
\hline Total Chol (mg/dL) & $209.53 \pm 44.85$ & 203.50 & $182 a$ & 104 & 352 \\
\hline LDL Chol (mg/dL) & $131.74 \pm 35.17$ & 127.50 & 114 & 63 & 218 \\
\hline $\mathrm{HDL}$ Chol (mg/dL) & $43.46 \pm 8.13$ & 43 & $41^{a}$ & 27 & 66 \\
\hline Triglyceride (mg/dL) & $194.85 \pm 185.17$ & 139 & $108^{a}$ & 53 & 1210 \\
\hline hsCRP (mg/L) & $1.52 \pm 1.29$ & 1.03 & $2.60^{\mathrm{a}}$ & 0.12 & 6,28 \\
\hline Creatinine $(\mathrm{mg} / \mathrm{dL})$ & $0.96 \pm 0.14$ & 0.95 & 1 & 0.70 & 1.30 \\
\hline eGFR $\left(\mathrm{mL} / \mathrm{min} / 1.73 \mathrm{~m}^{2}\right)$ & $88.94 \pm 15.58$ & 89 & $89 a$ & 61 & 126 \\
\hline
\end{tabular}

Abbreviations: $\mathrm{SD}=$ Standard Deviation; BMI = Body Mass Index ; WC = Waist Circumference; PTH = Parathyroid Hormone; FG = Fasting Glucose; HOMA-IR = homeostasis model assessment - Insulin Resistance; AST = Aspartate Aminotransferase; ALT = Alanine Aminotransferase; eGFR = Estimation Glomeroulus Filtration Rate 
Table 2. Independent Sample T Test between non obese group and central obese group

\begin{tabular}{lccc}
\hline BMP2 $(\mathbf{p g} / \mathrm{mL})$ & & (min-max) & Mean \pm SD \\
\hline Age & $38.60 \pm 6.39$ & $41.75 \pm 5.93$ & 0.047 \\
WC & $78.85 \pm 4.42$ & $97.54 \pm 5.95$ & 0.000 \\
SBP & $110.25 \pm 13.03$ & $123.42 \pm 9.28$ & 0.000 \\
DBP & $74.50 \pm 8.26$ & $81.48 \pm 7.92$ & 0.001 \\
FBP & $96.05 \pm 7.51$ & $93.43 \pm 10.07$ & 0.290 \\
Total Chol & $197.90 \pm 31.42$ & $213.40 \pm 48.11$ & 0.182 \\
LDL Chol & $127.00 \pm 24.22$ & $133.32 \pm 38.18$ & 0.490 \\
HDL Chol & $47.60 \pm 7.78$ & $42.08 \pm 7.83$ & 0.008 \\
Triglyceride & $114.80 \pm 52.53$ & $221.53 \pm 205.25$ & 0.000 \\
hsCRP & $0.90 \pm 0.97$ & $1.72 \pm 1.33$ & 0.012 \\
eGFR & $95.55 \pm 13.92$ & $86.73 \pm 15.59$ & 0.027 \\
ADMA & $0.59 \pm 0.09$ & $0.65 \pm 0.12$ & 0.043 \\
Ghrelin Total & $602.60 \pm 349.18$ & $478.43 \pm 175.82$ & 0.141 \\
& & & \\
\hline
\end{tabular}

Table 3. Correlation between total ghrelin and ADMA

\begin{tabular}{lcc}
\hline Group & $\mathbf{r}$ & $\mathbf{p}$ \\
\hline Non obese & -0.112 & 0.638 \\
Central obese & 0.066 & 0.614 \\
Obese non metabolic syndrome & 0.194 & 0.257 \\
Metabolic syndrome & -0.259 & 0.221
\end{tabular}




\section{Discussion}

\section{Association between waist circumference and total ghrelin}

The brain has a role to regulate energy homeostasis in response to signals from both the adipose tissue and the gastrointestinal tract. Regulation of energy homeostasis is important to keep the body weight stable through the balance between the drive to eat and energy expenditure (7). Ghrelin, a gut hormone produced in the gaster exerts pleiotropic biological actions, prominently in the regulation of food intake and energy homeostasis (1). Total ghrelin concentrations in our study tended to significantly correlate negatively with waist circumference $\left(r=-0.244^{*}\right.$, $\mathrm{p}$-value $=0.029)$ and BMI $(\mathrm{r}=-0.261$, $\mathrm{p}$-value $=0.019)$.

Based on the mean data of total ghrelin, it showed a decrease of the total ghrelin concentration in the group with centrally obese men as compared with the total ghrelin concentration in the group of non-obese men, but the difference was not significant ( $\mathrm{p}$-value $=0.141)$. Tschöp et al. reported a decrease of plasma ghrelin concentration in obese Caucasians as compared with lean Caucasians (p-value < 0.01) (8). The decrease of ghrelin concentration in obese men is a response to keep the balance of energy. Recent evidence has demonstrated that ghrelin regulates central and peripheral lipid metabolism through specific control of hypothalamic AMP-activated protein kinase (AMPK) (9). Although there was a correlation of total ghrelin and waist circumference with BMI, but there was no significant difference in total ghrelin concentration between non obese and central obesity group (p-value $>$ 0.05 ). If the total ghrelin concentrations were compared between non obese, obese without metabolic syndrome (mets) and obese with mets, there was a significant correlation between non obese and obese with mets (p-value $<0.05$ ), but there was no significant correlation between non obese and obese without mets. Pulkkinen et al. have also reported that total ghrelin concentrations are lower in obese patients with metabolic syndrome compared to non-obese as control (10). This research has showed that total ghrelin concentrations did not yet decreased in obese subjects without mets because of the low degree of obesity. The decrease of the total ghrelin concentration was a response to modulate long term energy homeostasis. Beside enhancing appetite and increase food intake, ghrelin has another role to increase fat deposit by increasing the mRNA expression of fatty acid synthase (FAS), acetyl-CoA carboxylasealpha, stearoyl-CoA desaturase-1, and lipoprotein lipase, enzymes involved in increasing fat storage (1). The increase of visceral fat causes a decrease in total ghrelin production, so to suppress the fat deposit process.

There was also negative correlation between total ghrelin and FBG $(r=-0.221$, p-value $=0.049)$, but no correlation was found between total ghrelin and HDL cholesterol, log triglyceride and blood pressure. The negative correlation between total ghrelin and FBG showed us that the decrease of total ghrelin in subjects with hyperglycemia was a response of ghrelin to modulate the energy homeostasis. There was also negative correlation between total ghrelin and log triglyceride in centrally obese group $\left(r=-0.255^{*}\right.$; $p$-value $\left.=0.049\right)$. Ghrelin has a role to suppress fat deposit in obese subjects.

Low-concentration of total ghrelin has been independently associated with elevated blood pressure (BP) (11). But in this research, there was no correlation found between total ghrelin and BP. The difference results can occur because the difference of methods of designs. In this research, the subjects with hypertension were only 14 persons, prehypertension 52 persons, and normotensive 14 persons. Because of the number of hypertensive subjects was only 14 persons (hypertension level I 11 persons; hypertension level II 3 persons), there was no difference or significant correlation between total ghrelin and blood pressure.

\section{Association between waist circumference and ADMA}

ADMA competes with arginine for substrate-binding sites of NOS. Increased ADMA inhibits activity of all 3 NOS isoforms (12). Elevated concentrations of ADMA inhibit NO production and therefore impair endothelial function which can increase risk of atherosclerosis. ADMA concentrations can be influenced by hypercholesterolemia, atherosclerosis, hypertension, chronic heart failure, diabetes mellitus and chronic renal failure (6).

In this study, no significant correlation was found between ADMA and waist circumference $(r=0.206$, p-value $=0.067$ ), but there was a significant difference of ADMA concentration between non-obese and central obese group ( $\mathrm{p}=0.043$, $\mathrm{p}$-value $<0.05$ ). Some studies reported that there was a significant correlation between ADMA and WC. Koc showed that there was a significant positive correlation between ADMA and WC. Mean of BMI in that study was $35 \pm 4 \mathrm{~kg} / \mathrm{m}^{2}$ and mean of WC was $111 \pm 11 \mathrm{~cm}$ (13). Another study also reported that there was a significant positive correlation in older adults with BMI mean $28.4 \pm 5.2 \mathrm{~kg} / \mathrm{m}^{2}(\mathrm{r}=0.10$, p-value < $0.01)(14)$. The results of that study as compared with our 
results showed a difference in the mean of BMI an also WC. The difference in the study design and the number of the subjects involved in this study can be the reason why there was no correlation between ADMA and WC or BMI in this study. Even there was no correlation, we found that there was a significant difference of ADMA concentration between non-obese and centrally obese group.

There was a positive significant correlation between ADMA and Diastolic Blood Pressure (DBP) ( $r=0.319^{* *}$, $\mathrm{p}$-value $=0.004)$, between ADMA and Log trygliceride $\left(\mathrm{r}=0.348^{* *}, \mathrm{p}\right.$-value $\left.=0.002\right)$, and there was a negative significant correlation between ADMA and HDL cholesterol $\left(\mathrm{r}=-0.335^{* *}, \mathrm{p}\right.$-value $\left.=0.002\right)$. Akira Ito $e t$ al. reported that plasma concentrations of ADMA were elevated in individuals with hypercholesterolemia or atherosclerosis. Their results reveal that lipoproteins or cytokines may cause increase of ADMA concentration by reducing dimethylarginine dimethylaminohydrolase (DDAH) activity (15).

There are two isoforms of DDAH that metabolize ADMA. DDAH-1 is the prime isoform that is found in the proximal tubules of the kidney and in the liver. These organs extract ADMA from the circulation. DDAH-2 is the prime isoform in the vasculature and is also expressed in the kidney in the macula densa and distal nephrons. The activation of angiotensin type 1 receptor in the kidneys reduces the expression of DDAH-1 but increases the expression of DDAH-2. The elevated blood pressure through the activation of angiotensin system can increase ADMA concentration because it causes the decrease in DDAH activity, implying a decrease in ADMA secretion (16).

\section{Association between total ghrelin and ADMA}

Ghrelin has a role in cardiovascular system probably mediated by ghrelin receptor rather than by $\mathrm{GH}$. It has been reported that ghrelin receptor is detected in the cardiovascular system. Administration of ghrelin in persons with mets has shown to improve endothelial function by preventing proatherogenic changes and improving vasodilatation, and by decreasing blood pressure (BP) without increase in heart rate (10).

Ghrelin has a role in inducing phosphorylation of eNOS in an activation site and production of NO in ECs. Xu et al. have demonstrated that ghrelin stimulates AMPK and Akt activation through GHSR- and CaMKKdependent pathway. AMPK and Akt have been suggested to phosphorylate human eNOS at Ser-1177, with increasing activity of eNOS in response to various stimuli. These cumulative observations may represent an important mechanism of ghrelin in cardiovascular system (5).
Based on the studies on the role of ghrelin and ADMA in NO production, we tried to find the correlation between total ghrelin and ADMA, which can increase the risk factor of endothelial dysfunction. The results showed that there was no significant correlation between total ghrelin and ADMA ( $\mathrm{r}=-0.045$, $\mathrm{p}$-value $>0.05)$. It became clear that ghrelin influences vascular function directly to production of NO. In human aortic endothelial cells, ghrelin promotes NO synthesis by GHSR-1a, phosphoinositide-3 (PI3K), Akt, and eNOS pathways. Another report suggested that ghrelin may modulate the vascular tone by negative regulation of mRNA expression of prostaglandinendoperoxide synthase-2 (COX2), eNOS, and inducible NO synthetase (iNOS). Another report suggested that ghrelin has a contractile activity by facilitation of endothelin-1(ET-1) triggered intracellular signaling in smooth muscle cells, including phospholipase C (PLC), Rho-kinase, and intracellular InsP3-sensitive $\mathrm{Ca}^{+}$release, and/or by stimulating the release of a yet unknown contractile mediator from the endothelium (11).

\section{Conclusions}

In this study no significant decrease of the total ghrelin concentration was found, but a significant increase of ADMA concentration was noted in obese men as compared with that in non obese men. A significant decrease of total ghrelin concentration was seen in obese men with metabolic syndrome, indicating ghrelin concentration is decreased significantly in high obesity degree. In this study, there was no correlation between ADMA and WC or BMI which may be attributed to the difference in the study design used and the number of subjects involved. In this study, there was no correlation between total ghrelin and ADMA. We demonstrated that ghrelin influenced vascular function without synthesizing ADMA. In the future, indepth elucidation of the mechanism by which ghrelin plays role in cardiovascular homeostasis regulation should be made a focal point of study.

\section{Acknowledgement:}

We thank the Prodia Education and Research Institute for the invaluable support to this study. 


\section{References:}

1. Stengel A, Taché Y. Ghrelin -A Pleiotropic Hormone Secreted from Endocrine X/A-Like Cells of The Stomach. Front Neurosci. 2012; 6: 24.

2. Tesauro, M., Schinzari, F., Caramanti, M., Lauro, R., Cardillo, C. Metabolic and Cardiovascular Effects of Ghrelin. Int J Pept. 2010; 2010. pii: 864342.

3. Yin X, Li Y, Xu G, An W, Zhang W. Ghrelin Fluctuation, What Determines Its Production?. Acta Biochim Biophys Sin. 2009; 41: 188-97.

4. Pacifico L, Poggiogalle E, Costantino F, Anania C, Ferraro F, Chiarelli F, et al. Acylated and Nonacylated Ghrelin Levels and Their Associations with Insulin Resistance in Obese and Normal Weight Children with Metabolic Syndrome. Eur J Endocrinol 2009; 161: 861-70.

5. Xu X, Jhun BS, Ha CH, Jin ZG. Molecular Mechanisms of Ghrelin-Mediated Endothelial Nitric Oxide Synthase Activation. Endocrinology. 2008; 149: 4183-92.

6. Sibal L, Agarwal SC, Home PD, Boger RH. The Role of Asymmetric Dimethylarginine (ADMA) in Endothelial Dysfunction and Cardiovascular Disease. Curr Cardiol Rev. 2010; 6: 82-90.

7. Stanley S, Wynne K, McGowan B, Bloom S. Hormonal Regulation of Food Intake. Physiol. Rev. 2005; 85: 113158.

8. Tschöp M, Weyer C, Tataranni PA, Devanarayan V, Ravussin E, Heiman ML. Circulating Ghrelin Levels Are Decreased in Human Obesity. Diabetes. 2001; 50: 707-9.
9. Varela L, Vázquez MJ, Cordido F, Nogueiras R, VidarPuig A, Diéguez C, et al. Ghrelin and lipid metabolism: key partners in energy balance. J. Mol. Endocrinol. 2011; 46: R43-63.

10. Pulkkinen L, Ukkola O, Kolehmainen M, Uusitupa M. Ghrelin in Diabetes and Metabolic Syndrome Int J Pept. 2010;2010. pii: 248948.

11. Zhang G, Yin X, Qi Y, Pendyala L, Chen J, Hou D, et al. Ghrelin and Cardiovascular Diseases. Curr. Cardiol. Rev. 2010; 6: 62-70.

12. Böger RH, Sullivan LM, Schwedhelm E, Wang TJ, Maas R, Benjamin EJ, et al. Plasma Asymmetric Dimethylarginine and Incidence of Cardiovascular Disease and Death in the Community. Circulation. 2009; 119: 1592-600.

13. Koc F, Tokac M, Erdem S, Kaya C, Unlu A, Karabag T, et al. Serum asymmetric dimethylarginine levels in normotensive obese individuals. Med Sci Monit. 2010 ; 16: CR536-9.

14. Sydow K, Fortmann SP, Fair JM, Varady A, Hlatky MA, Go AS, et al. Distribution of Asymmetric Dimethylarginine among 980 Healthy, Older Adults of Different Ethnicities. Clin. Chem. 2010; 56: 111-20.

15.Ito, A., Tsao, P.S., Adimoolam, S., Kimoto, M., Ogawa, T., Cooke, J.P. Novel Mechanism for Endothelial Dysfunction: Dysregulation of Dimethylarginine Dimethylaminohydrolase. Circulation, 1999; 99: 3092-3095.

16.Palm, F., Onozato, M.L., Luo, Zaiming, Wilcox, C.S. 2007. Dimethylarginine Dimethylaminohydrolase (DDAH): Expression, Regulation, and Function in The Cardiovascular and Renal Systems. Am. J. Physiol. Heart Circ. Physiol. 2007; 293: H3227-45. 